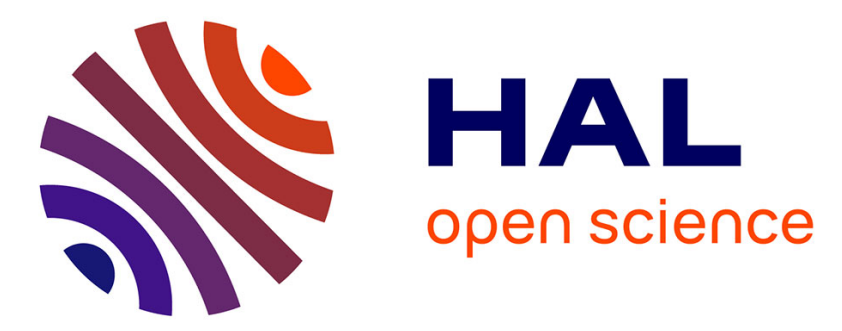

\title{
Patterns of mass, carbon and nitrogen in coarse woody debris in five natural forests in southern China
}

Jianfen Guo, Guangshui Chen, Jinsheng Xie, Zhijie Yang, Yusheng Yang

\section{To cite this version:}

Jianfen Guo, Guangshui Chen, Jinsheng Xie, Zhijie Yang, Yusheng Yang. Patterns of mass, carbon and nitrogen in coarse woody debris in five natural forests in southern China. Annals of Forest Science, 2014, 71 (5), pp.585-594. 10.1007/s13595-014-0366-4 . hal-01102597

\section{HAL Id: hal-01102597 \\ https://hal.science/hal-01102597}

Submitted on 13 Jan 2015

HAL is a multi-disciplinary open access archive for the deposit and dissemination of scientific research documents, whether they are published or not. The documents may come from teaching and research institutions in France or abroad, or from public or private research centers.
L'archive ouverte pluridisciplinaire HAL, est destinée au dépôt et à la diffusion de documents scientifiques de niveau recherche, publiés ou non, émanant des établissements d'enseignement et de recherche français ou étrangers, des laboratoires publics ou privés. 


\title{
Patterns of mass, carbon and nitrogen in coarse woody debris in five natural forests in southern China
}

\author{
Jianfen Guo • Guangshui Chen • Jinsheng Xie • \\ Zhijie Yang • Yusheng Yang
}

Received: 10 September 2013 / Accepted: 27 February 2014 / Published online: 27 March 2014

(C) INRA and Springer-Verlag France 2014

\begin{abstract}
- Context Coarse woody debris (CWD, $\geq 10 \mathrm{~cm}$ in diameter) is an important structural and functional component of forests. There are few studies that have estimated the mass and carbon (C) and nitrogen $(\mathrm{N})$ stocks of CWD in subtropical forests. Evergreen broad-leaved forests are distributed widely in subtropical zones in China.

- Aims This study aimed to evaluate the pools of mass, $\mathrm{C}$ and $\mathrm{N}$ in CWD in five natural forests of Altingia gracilipes Hemsl., Tsoongiodendron odorum Chun, Castanopsis carlesii (Hemsl.) Hayata, Cinnamomum chekiangense Nakai and Castanopsis fabri Hance in southern China.

- Methods The mass of CWD was determined using the fixed-area plot method. All types of CWD (logs, snags, stumps and large branches) within the plot were measured.
\end{abstract}

\section{Handling Editor: Andreas Bolte}

Contribution of the co-authors Y. Yang and J. Guo designed the research, J. Guo, J. Xie and Z. Yang collected the data. J. Guo and G. Chen performed analysis and calculations. J. Guo wrote the manuscript. Y. Yang and G. Chen commented on the manuscript.

J. Guo $\cdot$ G. Chen $\cdot$ J. Xie $\cdot$ Z. Yang $\cdot$ Y. Yang $(\bowtie)$

College of Geographical Science, Fujian Normal University, No.32

Shangsan Road, Cangshan District, Fuzhou 350007, China

e-mail: geoyys@fjnu.edu.cn

J. Guo

e-mail: jfguo@fjnu.edu.cn

G. Chen

e-mail: gshuichen@163.com

J. Xie

e-mail: jshxie@163.com

Z. Yang

e-mail: daoyang9@163.com

J. Guo $\cdot$ G. Chen $\cdot$ J. Xie $\cdot$ Z. Yang $\cdot$ Y. Yang

Key Laboratory for Subtropical Mountain Ecology, Fuzhou 350007, China
The species, length, diameter and decay class of each piece of CWD were recorded. The $\mathrm{C}$ and $\mathrm{N}$ pools of CWD were calculated by multiplying the concentrations of $\mathrm{C}$ and $\mathrm{N}$ by the estimated mass in each forest and decay category.

- Results Total mass of CWD varied from $16.75 \mathrm{Mg} \mathrm{ha}^{-1}$ in the $C$. fabri forest to $40.60 \mathrm{Mg} \mathrm{ha}^{-1}$ in the $A$. gracilipes forest; of this CWD, the log contribution ranged from 54.75 to $94.86 \%$. The largest CWD ( $\geq 60 \mathrm{~cm}$ diameter) was found only in the A. gracilipes forest. CWD in the $40-60 \mathrm{~cm}$ size class represented above $65 \%$ of total mass, while most of CWD accumulations in the C. carlesii, C. chekiangense and C. fabri forests were composed of pieces with diameter less than $40 \mathrm{~cm}$. The A. gracilipes, T. odorum, C. carlesii and $C$. chekiangense forests contained the full decay classes (from 1 to 5 classes) of CWD. In the C. fabri forest, the CWD in decay classes 2-3 accounted for about $90 \%$ of the total CWD mass. Increasing $\mathrm{N}$ concentrations and decreasing densities, $\mathrm{C}$ concentrations, and $\mathrm{C}: \mathrm{N}$ ratios were found with stage of decay. Linear regression showed a strong correlation between the density and C:N ratio $\left(R^{2}=0.821\right)$. CWD C-stock ranged from 7.62 to $17.74 \mathrm{Mg} \mathrm{ha}^{-1}$, while the $\mathrm{N}$ stock varied from 85.05 to $204.49 \mathrm{~kg} \mathrm{ha}^{-1}$. The highest overall pools of C and N in CWD were noted in the $A$. gracilipes forest.

- Conclusion Differences among five forests can be attributed mainly to characteristics of the tree species. It is very important to preserve the current natural evergreen broad-leaved forest and maintain the structural and functional integrity of CWD.

Keywords Coarse woody debris $\cdot$ Mass $\cdot$ Carbon $\cdot$ Nitrogen . Natural forest $\cdot$ Southern China

\section{Introduction}

Coarse woody debris (CWD) is generally defined as dead woody material with a diameter of $10 \mathrm{~cm}$ or greater. This 
includes a range of woody debris from fallen logs and branches to standing dead trees (also called stags or snags) and stumps. CWD is an important structural component of forest ecosystems and plays a critical role in ecosystem process and functioning (Harmon et al. 1986). It provides food and habitat for wildlife, reduces runoff, and is an integral component of nutrient cycling (Grove and Meggs 2003). CWD also contributes substantially to the long-lived forest carbon pool, a fact that is often overlooked (Clark et al. 2002). With recognition of its important role in material cycle and energy flow in ecosystems, CWD in forest ecosystems has been studied since the late 1970s. However, most studies on CWD have been conducted in temperate forests in North America and North Europe, and only a few studies have been conducted in tropical or subtropical forests (Harmon et al. 1995; Santiago 2000; Iwashita et al. 2013).

In China, CWD had not been studied until the early 1990s (Chen and Xu 1991; Hou and Pan 2001; Deng et al. 2002), and so far there is very limited information available on CWD function in forest ecosystems. Studies on CWD in China have focused mostly on coniferous forests (Yang et al. 2002), such as Korean pine mixed forests (Dai et al. 2000), and Abies fargesii Franch. forests in temperate zones ( $\mathrm{Li}$ et al. 1998). Evergreen broad-leaved forests are distributed widely in subtropical zones in China. The subtropical region occupies onequarter of the total area of the country. There is a very rich diversity of plant species distributed throughout the evergreen forest area (Wu 1980). Therefore, more studies should be performed in subtropical forests to obtain better insight into the influence of tree species on CWD.

CWD acts as a long-term stabilizing pool for nutrients and can enhance forest soil fertility and productivity (Keenan et al. 1993; Clark et al. 2002; Mackensen et al. 2003). Assessing the function of CWD in nutrient cycling requires partitioning of the rates of inputs and decomposition of CWD relative to other litter types. In general, it is difficult to directly measure CWD input and decomposition due to its considerable temporal and spatial variations (e.g., Forrester et al. 2012). Most previous studies for estimating rates of decomposition have used indirect methods, such as back-dating or chronosequence techniques (Laiho and Prescott 1999). These rough estimates may be adequate for management guidelines, but more precise information on the patterns of mass, carbon and nutrient release from CWD is necessary for ecosystem modeling to better understand the role of CWD in various forest ecosystems. In order to obtain precise and more reliable information on CWD dynamics, the species or forest type effects cannot be neglected. In this study, we selected five important forest types in Wanmulin Nature Reserve in subtropical zone of China to examine the effects on the patterns of mass, carbon and nitrogen in CWD. We focused on the natural forests of Altingia gracilipes Hemsl., Tsoongiodendron odorum Chun, Castanopsis carlesii (Hemsl.) Hayata, Cinnamomum chekiangense Nakai and Castanopsis fabri Hance without evidence of past human disturbances in the reserve. Our objectives were to: (1) characterize the amount and the distribution of CWD in five natural forests, and (2) estimate $\mathrm{C}$ and $\mathrm{N}$ pools in CWD in these forests.

\section{Materials and methods}

\subsection{Study area}

The study was carried out in Wanmulin Nature Reserve in Jianou, Fujian $\left(27^{\circ} 03^{\prime} \mathrm{N}, 118^{\circ} 09^{\prime} \mathrm{E}, 230-556 \mathrm{~m}\right.$ a.s.l.). It borders Jiufeng Mountain on the southeast and Wuyi Mountain on the northwest. The region is located within a middle subtropical monsoonal climate zone, with a mean annual air temperature of $19.4{ }^{\circ} \mathrm{C}$ and relative humidity of $81 \%$. The mean annual precipitation is $1,731 \mathrm{~mm}$, which occurs mainly from March to August. Mean annual evapotranspiration is $1,466 \mathrm{~mm}$. The growing season is relatively long with an annual frost-free period of around 277 days (Lin et al. 2011). The soils are developed on granite and are classified as humic Planosols (red soils). The thickness of the soils exceeds $1.0 \mathrm{~m}$ (Yang et al. 2005).

Wanmulin Nature Reserve includes a total area of 189 ha evergreen broad-leaved forests. The forests have been well protected as natural succession for $>600$ years and mean tree age ranges from 120 to 150 years old. Some dominant species, such as T. odorum and C. carlesii, are characteristic of a climax vegetation. Based on facts such as the presence of large, old trees, and the lack of widespread human disturbance prior to the establishment of the Reserve, these old-growth forests are an ideal site to examine the CWD dynamics of evergreen broad-leaved trees in a subtropical region in China. The detailed information on the selected forests and their surface soils $(0-20 \mathrm{~cm})$ is shown in Table 1 (Yang et al. 2005).

\subsection{CWD mass and contents of $\mathrm{C}$ and $\mathrm{N}$}

In 2008 , three $20 \mathrm{~m} \times 20 \mathrm{~m}$ plots were established randomly in each forest of $A$. gracilipes, T. odorum, C. carlesii, $C$. chekiangense and C. fabri. The mass of CWD was determined using the fixed-area plot method (Harmon and Sexton 1996). All types of CWD (logs, snags, stumps and large branches) within the plot were measured. Logs were downed or leaning deadwood with their minimum diameter $\geq 10 \mathrm{~cm}$ at the widest point and length $\geq 1 \mathrm{~m}$. Dead trees with a gradient (departure from vertical direction) $\leq 45^{\circ}$ and the diameter at the widest point $\geq 10 \mathrm{~cm}$ were classified as snags, while those with a gradient $>45^{\circ}$ were classified as logs. Stumps were defined as vertical deadwood $\leq 1 \mathrm{~m}$ in height and $\geq 10 \mathrm{~cm}$ at the widest point in diameter (Harmon and Sexton 1996). The species, length and diameter of each piece of CWD were 
Table 1 Forest characteristics and soil properties of the study sites (Yang et al. 2005)

\begin{tabular}{|c|c|c|c|c|c|}
\hline \multirow[t]{2}{*}{ Parameter } & \multicolumn{5}{|l|}{ Forest type } \\
\hline & Altingia gracilipes & $\begin{array}{l}\text { Tsoongiodendron } \\
\text { odorum }\end{array}$ & Castanopsis carlesii & Cinnamomum chekiangense & $\begin{array}{l}\text { Castanopsis } \\
\text { fabri }\end{array}$ \\
\hline Mean tree age $(\text { year })^{\mathrm{a}}$ & 150 & 120 & 120 & 150 & 120 \\
\hline Mean tree height $(\mathrm{m})^{\mathrm{a}}$ & 28 & 28 & 23 & 26 & 25 \\
\hline Mean tree diameter at breast height $(\mathrm{cm})^{\mathrm{a}}$ & 45.2 & 42.2 & 29.4 & 36.4 & 31.1 \\
\hline Stand density $\left(\text { stem ha }{ }^{-1}\right)^{\mathrm{a}}$ & 235 & 298 & 306 & 338 & 275 \\
\hline Stand volume $\left(\mathrm{m}^{3} \mathrm{ha}^{-1}\right)^{\mathrm{a}}$ & 406 & 423 & 251 & 368 & 278 \\
\hline \multirow[t]{3}{*}{ Dominant tree species ${ }^{\mathrm{b}}$} & A. gracilipes & T. odorum & C. carlesii & C. chekiangense & C. fabri \\
\hline & C. carlesii & S. superba & Elaeocarpus decipiens & Sycopsis dunnii & S. superba \\
\hline & Schima superba & Sloanea sinensis & S. superba & S. superba & C. carlesii \\
\hline \multicolumn{6}{|l|}{ Soil (top 0-20 cm depth) } \\
\hline Bulk density $\left(\mathrm{g} \mathrm{cm}^{-3}\right)$ & 0.90 & 0.92 & 0.74 & 0.95 & 0.85 \\
\hline Organic matter $(\%)$ & 6.3 & 4.1 & 3.8 & 4.0 & 2.8 \\
\hline Total N (\%) & 0.17 & 0.15 & 0.13 & 0.17 & 0.12 \\
\hline Total P (\%) & 0.04 & 0.04 & 0.04 & 0.05 & 0.03 \\
\hline Hydrolyzable $\mathrm{N}\left(\mathrm{mg} \mathrm{kg}^{-1}\right)$ & 164 & 140 & 147 & 112 & 131 \\
\hline Available P $\left(\mathrm{mg} \mathrm{kg}^{-1}\right)$ & 1.67 & 2.42 & 2.11 & 1.71 & 2.95 \\
\hline
\end{tabular}

${ }^{a}$ Only dominant tree species whose importance value is first on the list are considered

${ }^{\mathrm{b}}$ Species composition is ranked in descending order according to importance values (Kent and Coker 1992) and only the three most dominant tree species are listed

recorded. The length of CWD was measured to the nearest $0.1 \mathrm{~cm}$. When the CWD extended to the outside of the plot, only the part within the plot was measured. The heights of a snag were estimated with a clinometer (Vertex III, Haglöf, Sweden). The total volume of the CWD was calculated using the formula: $V=\pi L\left(D_{\mathrm{b}}^{2}+\mathrm{D}_{\mathrm{t}}^{2}\right) / 8$ or $V=\pi L D_{\mathrm{m}}^{2} / 4$, where $V, L, D_{\mathrm{b}}$, $D_{\mathrm{m}}$, and $D_{\mathrm{t}}$ are the volume, length, and diameter of the base, midpoint, and top of the CWD, respectively.

We separated CWD into four size classes based on diameter: 10 to $<20 \mathrm{~cm}, 20$ to $<40 \mathrm{~cm}, 40$ to $<60 \mathrm{~cm}$, and $\geq 60 \mathrm{~cm}$. Each piece of CWD was classified according to a five class system (Sollins et al. 1987; Tang and Zhou 2005): class 1: freshly fallen log with sound wood, intact bark and twigs intact, original color; class 2: initial rotting of the sapwood, bark and heartwood sound, twigs absent, original color; class 3: bark sloughs, sapwood decayed but still present, heartwood decayed but structurally sound, reddish-brown or original color; class 4: sapwood has rotted, bark absent, branches can be removed easily, heartwood is thoroughly rotted and color of wood is reddish or light brown; class 5: heartwood fragmented and settled into the ground as elongate mounds, red-brown or light brown.

Coarse woody debris mass was calculated as the product of CWD volume and decay class-specific densities. To determine wood density, we cut small pieces of wood $(n=3)$ from dominant species of CWD in each decay class. Each fragment was dried at $70^{\circ} \mathrm{C}$ to constant weight (approximately 1 week) and weighed. The volume of fragments was then determined using the water displacement method (Chave et al. 2006). Finally, wood density was estimated as the ratio of dry mass to volume. We assumed the same wood density values for the same species at the same decay class among logs, snags, stumps and branches.

To determine the $\mathrm{C}$ and $\mathrm{N}$ concentrations of the $\mathrm{CWD}$, nine representative samples were taken from pieces of CWD chosen randomly from each decay class across three plots in each forest, and ground finely to pass through a 1-mm mesh screen. A well-homogenized subsample was then analyzed for $\mathrm{C}$ and $\mathrm{N}$ with an ELEMEMTAR Vario EL III CN Analyzer. The C and $\mathrm{N}$ pools of CWD were calculated as the product of CWD mass and decay class-specific $\mathrm{C}$ and $\mathrm{N}$ concentrations.

\subsection{Statistical analysis}

Analyses of variance (ANOVA) with post hoc Tukey's test were used to determine significant effects of forest type, diameter class, and decay class on mass of CWD components and pools of $\mathrm{C}$ and $\mathrm{N}$. Linear regression was used to assess the relationship between the density and C:N ratio of CWD with forest type as a covariable. Statistical significance was established at the $5 \%$ level, unless otherwise mentioned. All statistical analyses were done using SPSS software (SPSS 13.0 for windows, SPSS, Chicago, IL). 


\section{Results}

\subsection{Total mass of CWD}

The total volume of CWD ranged from $48.0 \mathrm{~m}^{3} \mathrm{ha}^{-1}$ in the $C$. carlesii forest to $100.4 \mathrm{~m}^{3} \mathrm{ha}^{-1}$ in the $A$. gracilipes forest. The lowest value of total mass was found in the C. fabri forest $\left(16.75 \mathrm{Mg} \mathrm{ha}^{-1}\right)$ and the highest was in the A. gracilipes forest (40.60 $\mathrm{Mg} \mathrm{ha}^{-1}$ ) (Table 2). The mass of logs in the A. gracilipes forest was significantly higher than those in other natural forests. The T. odorum forest had a significantly higher mass of snags. The A. gracilipes and $C$. fabri forests had intermediate values of mass of snags followed by the $C$. carlesii forest, while the C. chekiangense forest had the lowest value. A significantly higher mass of large branches was found in the C. carlesii forest, while there was no big difference between the $A$. gracilipes and $C$. fabri forests in the mass of stumps and large branches. Of the total CWD mass in the five forests, the logs comprised 54.75$94.86 \%$, representing the main component of CWD.

\subsection{Diameter classes distribution of CWD}

The $C$. carlesii and $C$. fabri forests had a significantly higher proportion of CWD in the 10-20 cm size class $(39.42 \%$ and $36.27 \%$, respectively) than other forests. The T. odorum forest had the lowest proportion of CWD at the diameter of 20 $40 \mathrm{~cm}$. The mass percentage of CWD at the diameter of 40 $60 \mathrm{~cm}$ ranged from $4.95 \%$ in the $C$. fabri forest to $67.17 \%$ in the $T$. odorum forest. There was a large variation in the diameter classes distribution of CWD in each forest (Table 3). The largest CWD ( $\geq 60 \mathrm{~cm}$ diameter) was found only in the A. gracilipes forest. CWD in the $40-60 \mathrm{~cm}$ size class was the main component in the T. odorum forest and represented above $65 \%$ of total mass. While most of CWD accumulations in the $C$. carlesii, C. chekiangense and C. fabri forests were composed of pieces with diameter $\leq 40 \mathrm{~cm}$.

\subsection{Decay classes distribution of CWD}

The distribution of CWD in different decay classes varied among forests (Fig. 1). The A. gracilipes, T. odorum, C. carlesii and C. chekiangense forests contained the full decay classes (from 1 to 5 classes) of CWD. The proportion of total CWD mass in decay class 1 was the highest in the C. chekiangense forest and lowest in the A. gracilipes forest. In the $C$. fabri forest, the CWD in decay classes 2-3 accounted for about $90 \%$ of the total CWD mass. Of total mass of CWD across five decay classes, the two categories (decay classes 4 5) comprised $8.5-36.8 \%$. 
Table 3 The mass percentage (\%) of different diameter classes of CWD in five natural forests. Values in parentheses indicate SE. Capital letters in each row indicate significant differences among forests $(P<0.05)$. Small letters in each column indicate significant differences among diameter classes $(P<0.05)$

\begin{tabular}{llllll}
\hline Diameter class & Forest type & & & \\
\cline { 2 - 6 } & Altingia gracilipes & Tsoongiodendron odorum & Castanopsis carlesii & Cinnamomum chekiangense & Castanopsis fabri \\
\hline $10-20$ & $20.64(1.82) \mathrm{c} \mathrm{D}$ & $23.46(1.99) \mathrm{b} \mathrm{CD}$ & $39.42(4.02) \mathrm{a} \mathrm{A}$ & $27.73(2.20) \mathrm{b} \mathrm{C}$ & $36.27(3.19) \mathrm{b} \mathrm{AB}$ \\
$20-40$ & $27.93(2.48) \mathrm{b} \mathrm{C}$ & $9.37(0.71) \mathrm{c} \mathrm{D}$ & $32.42(3.11) \mathrm{ab} \mathrm{C}$ & $72.27(6.72) \mathrm{a} \mathrm{A}$ & $58.78(5.64) \mathrm{a} \mathrm{AB}$ \\
$40-60$ & $15.62(1.21) \mathrm{d} \mathrm{C}$ & $67.17(5.90) \mathrm{a} \mathrm{A}$ & $28.16(2.50) \mathrm{b} \mathrm{B}$ & & $4.95(0.42) \mathrm{c} \mathrm{D}$ \\
$\geq 60$ & $35.81(3.07) \mathrm{a}$ & & & & \\
\hline
\end{tabular}

\subsection{Detrital chemistry and density}

The density of CWD was correlated significantly with its decay classes $(P<0.001)$. The $\mathrm{C}$ concentrations of $\mathrm{CWD}$ differed significantly across all decay categories $(P<0.001)$. Our results showed increasing $\mathrm{N}$ concentrations and decreasing $\mathrm{C}$ concentrations and $\mathrm{C}: \mathrm{N}$ ratios with stage of decay (Table 4). Generally, density and C:N ratio changes were more pronounced in classes $4-5$ than classes $2-3$.

There was a significant correlation $(r=0.906, P<0.001)$ between $\mathrm{C}: \mathrm{N}$ ratio and density loss of CWD across five natural forests. The CWD linear function had the $R^{2}$ value of 0.821 (Fig. 2). A decrease in density resulted in a corresponding decrease in the $\mathrm{C}: \mathrm{N}$ ratio.

\subsection{Pools of detrital mass, $\mathrm{C}$ and $\mathrm{N}$}

Quantities of mass, C and N of CWD in class 5 were significantly lower than all other classes in all forests. There were also significant differences in the mass and contents of $\mathrm{C}$ and $\mathrm{N}$ of CWD between class 2 and class 3 (Table 5). Generally, pools of mass, $\mathrm{C}$ and $\mathrm{N}$ of CWD in classes 1-3 were significantly greater than classes $4-5$, but mass and $\mathrm{N}$ content of
CWD at class 4 in the $A$. gracilipes forest was the greatest among the five decay classes.

The $A$. gracilipes forest had significantly greater overall pools of $\mathrm{C}$ and $\mathrm{N}$ in $\mathrm{CWD}$ than other forests. The lowest stocks of $\mathrm{C}$ and $\mathrm{N}$ in CWD were found in the C. fabri forest and $C$. chekiangense forest, respectively (Table 5).

\section{Discussion}

\subsection{Quantity and quality of CWD}

The total CWD volume found in the present study (48.0$100.4 \mathrm{~m}^{3} \mathrm{ha}^{-1}$ ) was comparable to mixed montane forests in Eastern Italian Alps (Castagneri et al. 2010). However, tropical montane wet forests have much more CWD, generally over $200 \mathrm{~m}^{3} \mathrm{ha}^{-1}$ (Santiago 2000; Iwashita et al. 2013). Total mass of CWD in five natural forests falls within the range recorded for worldwide subtropical and tropical evergreen forests (9.1-173 $\mathrm{Mg} \mathrm{ha}^{-1}$ ) (Yan et al. 2007). The CWD mass of $40.6 \mathrm{Mg} \mathrm{ha}^{-1}$ in the A. gracilipes forest is higher than that of tropical forests in Venezuela (1-30 $\mathrm{Mg} \mathrm{ha}^{-1}$ ) (Delaney et al. 1998) and subtropical evergreen broad-leaved forests in Wuyi
Fig. 1 Relative distribution of total mass of coarse woody debris (CWD) among five decay classes in five natural forests

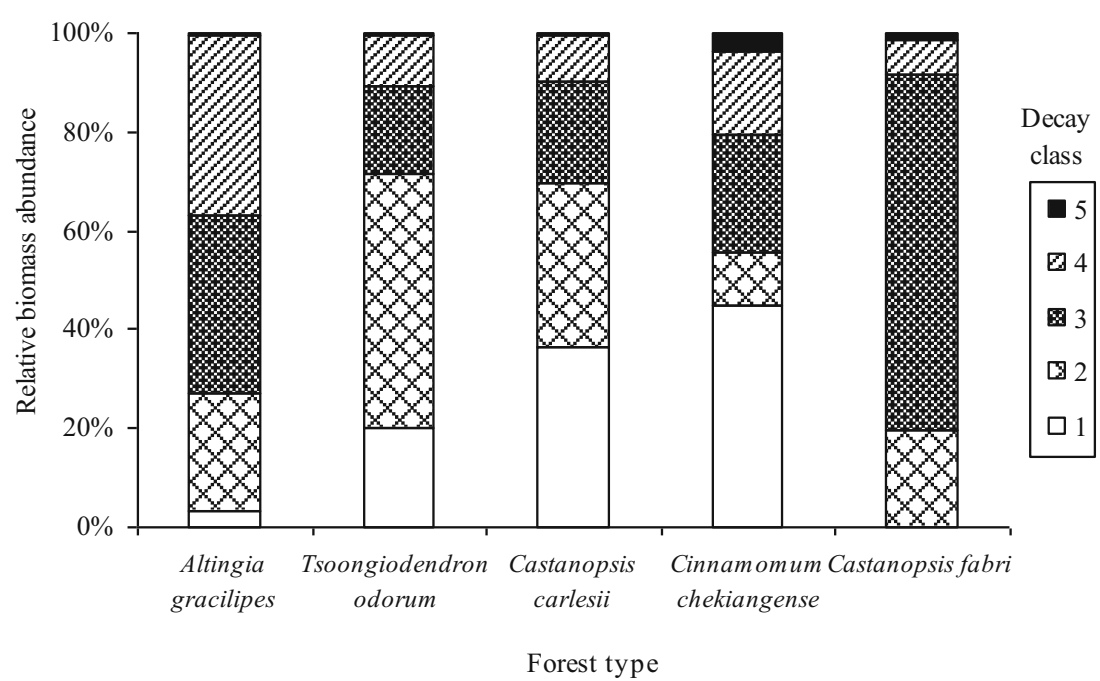

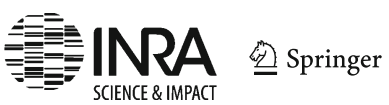


Table 4 Characteristics of CWD in five natural forests. Values in parentheses indicate SE. Values within the same column followed by the different small letter for each forest type are significantly different $(P<0.05)$ among different decay classes

\begin{tabular}{|c|c|c|c|c|c|}
\hline Forest type & Decay class & Density $\left(\mathrm{g} \mathrm{cm}^{-3}\right)$ & $\% \mathrm{C}$ & $\% \mathrm{~N}$ & $\mathrm{C}: \mathrm{N}$ ratio \\
\hline \multirow[t]{5}{*}{ Altingia gracilipes } & 1 & $0.50(0.03) \mathrm{a}$ & $45.6(2.3) \mathrm{a}$ & $0.42(0.16) a b$ & 109 (12) a \\
\hline & 2 & $0.48(0.02) \mathrm{ab}$ & $45.4(2.2) \mathrm{a}$ & $0.43(0.11) \mathrm{a}$ & $105(10)$ a \\
\hline & 3 & $0.44(0.02) b$ & $44.6(1.4) \mathrm{a}$ & $0.45(0.09) \mathrm{a}$ & 99 (11) a \\
\hline & 4 & $0.34(0.02) \mathrm{c}$ & $41.6(1.4) \mathrm{a}$ & $0.61(0.14) \mathrm{ab}$ & $68(7) b$ \\
\hline & 5 & $0.19(0.01) \mathrm{d}$ & $36.9(1.2) b$ & $0.79(0.19) b$ & $47(5) c$ \\
\hline \multirow[t]{5}{*}{ Tsoongiodendron odorum } & 1 & $0.57(0.03) \mathrm{a}$ & $49.0(1.5) \mathrm{a}$ & $0.35(0.05) \mathrm{a}$ & $140(16) \mathrm{a}$ \\
\hline & 2 & $0.49(0.03) b$ & $46.3(1.3) \mathrm{a}$ & $0.47(0.07) a b$ & $99(12) b$ \\
\hline & 3 & $0.37(0.02) \mathrm{c}$ & $43.4(1.0) \mathrm{bc}$ & $0.54(0.10) b$ & $80(9) \mathrm{bc}$ \\
\hline & 4 & $0.33(0.03) \mathrm{c}$ & $41.5(1.4) \mathrm{c}$ & $0.63(0.13) b c$ & $66(6) c$ \\
\hline & 5 & $0.13(0.02) \mathrm{d}$ & $31.3(0.8) \mathrm{d}$ & $0.87(0.13) \mathrm{c}$ & $36(4) d$ \\
\hline \multirow[t]{5}{*}{ Castanopsis carlesii } & 1 & $0.58(0.03) \mathrm{a}$ & $46.4(2.2) \mathrm{a}$ & $0.41(0.06) \mathrm{a}$ & $113(12) \mathrm{a}$ \\
\hline & 2 & $0.52(0.02) b$ & $45.5(1.8) \mathrm{a}$ & $0.57(0.11) \mathrm{ab}$ & $80(9) b$ \\
\hline & 3 & $0.33(0.02) \mathrm{c}$ & $43.4(1.7) \mathrm{a}$ & $0.65(0.13) b$ & $67(7) b c$ \\
\hline & 4 & $0.22(0.02) \mathrm{d}$ & $38.9(1.2) b$ & $0.69(0.13) b$ & $56(6) \mathrm{cd}$ \\
\hline & 5 & $0.16(0.02) \mathrm{e}$ & $33.2(0.7) \mathrm{c}$ & $0.72(0.14) b$ & $46(5) d$ \\
\hline \multirow[t]{5}{*}{ Cinnamomum chekiangense } & 1 & $0.49(0.03) \mathrm{a}$ & $46.8(1.5) \mathrm{a}$ & $0.42(0.07) \mathrm{a}$ & $111(13) \mathrm{a}$ \\
\hline & 2 & $0.41(0.02) \mathrm{b}$ & 46.5 (1.6) a & $0.46(0.08) \mathrm{a}$ & $101(10) \mathrm{a}$ \\
\hline & 3 & $0.35(0.03) \mathrm{c}$ & $43.5(1.8) \mathrm{a}$ & $0.49(0.10) \mathrm{a}$ & 89 (9) a \\
\hline & 4 & $0.27(0.01) \mathrm{d}$ & $39.9(0.9) b$ & $0.63(0.13) \mathrm{a}$ & $63(7) b$ \\
\hline & 5 & $0.12(0.01) \mathrm{e}$ & $29.4(0.7) \mathrm{c}$ & $0.66(0.15) \mathrm{a}$ & 45 (4) c \\
\hline \multirow[t]{5}{*}{ Castanopsis fabri } & 1 & - & - & - & - \\
\hline & 2 & $0.44(0.02) \mathrm{a}$ & $46.6(1.1) \mathrm{a}$ & $0.48(0.10) \mathrm{a}$ & $97(10) \mathrm{a}$ \\
\hline & 3 & $0.33(0.02) b$ & $45.7(1.2) \mathrm{a}$ & $0.52(0.08) \mathrm{a}$ & $88(9) a b$ \\
\hline & 4 & $0.27(0.02) \mathrm{c}$ & $41.0(0.7) b$ & $0.53(0.07) \mathrm{a}$ & $77(6) b$ \\
\hline & 5 & $0.15(0.01) \mathrm{d}$ & $39.0(0.8) \mathrm{c}$ & $0.64(0.12) \mathrm{a}$ & $61(5) c$ \\
\hline
\end{tabular}

mountain and Dinghushan nature reserve (7.3-25.3 $\mathrm{Mg} \mathrm{ha}^{-1}$ ) (Li et al. 1996; Tang et al. 2003), but it was somewhat lower than that of natural montane evergreen broad-leaved forest in Ailao Mountains (70.3 $\mathrm{Mg} \mathrm{ha}^{-1}$ ) and the temperate broadleaved evergreen forest in Chiloe Island, Chile (58$381 \mathrm{Mg} \mathrm{ha}^{-1}$ ) (Carmona et al. 2002). Further, CWD mass of other four natural forests at our site fell within the lower end of temperate deciduous forests elsewhere in the world (Harmon

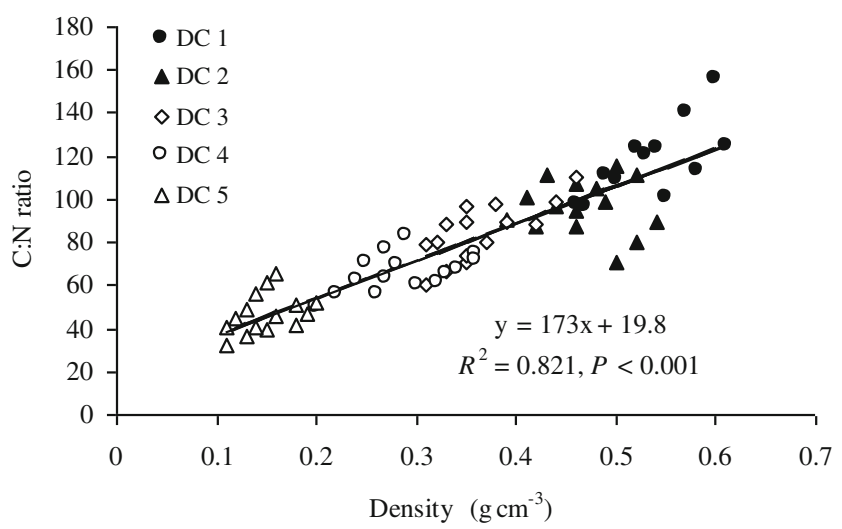

Fig. 2 Linear regression relating C:N ratio of CWD to density et al. 1986; Idol et al. 2001; Currie and Nadelhoffer 2002; Muller 2003). Overall, the large variations in the CWD estimates from the literature may be due to differences between forest types, decomposition rates, stand history and disturbance regimes (Yan et al. 2007; Schlegel and Donoso 2008). Significant differences were also observed in total CWD mass among the five natural forests (Table 2) in the same region, which could be due partly to the tree species effects. We found woody debris in the $A$. gracilipes forest is mainly of large diameter and low decay rate tree species (e.g., A. gracilipes with higher $\mathrm{C}: \mathrm{N}$ ratio compared to $C$. carlesii, unpublished data), which could contribute to CWD accumulation.

In this study, the high proportion of logs (especially larger diameter pieces) in CWD composition of the natural forest is similar to the old-growth forest ecosystems in other regions (Harmon et al. 1986; Spies et al. 1988; Siitonen et al. 2000). These CWD components resulted mainly from the natural senescence and death of old trees. This is the main route of woody debris accumulation in old-growth natural forests and is very common in other regions (Goodburn and Lorimer 1998; Liu et al. 2002; Webster and Jenkins 2005). On the other hand, the studied forests are natural old-growth forests 
Table 5 Pool sizes of CWD in five natural forests. Values in parentheses indicate SE. Values within the same column followed by the different capital letter or small letter for each forest type are significantly different $(P<0.05)$ among forests or different decay classes, respectively

\begin{tabular}{|c|c|c|c|c|c|}
\hline Forest type & Decay class & Volume $\left(\mathrm{m}^{3} \mathrm{ha}^{-1}\right)$ & Mass $\left(\mathrm{Mg} \mathrm{ha}^{-1}\right)$ & C pool $\left(\mathrm{Mg} \mathrm{ha}^{-1}\right)$ & $\mathrm{N}$ pool $\left(\mathrm{kg} \mathrm{ha}^{-1}\right)$ \\
\hline \multirow[t]{6}{*}{ Altingia gracilipes } & 1 & $2.5(0.8) \mathrm{c}$ & $1.24(0.27) \mathrm{c}$ & $0.57(0.07) \mathrm{c}$ & $5.21(0.57) \mathrm{d}$ \\
\hline & 2 & $20.4(4.6) \mathrm{b}$ & $9.79(1.98) b$ & $4.44(0.57) b$ & $42.10(5.89) \mathrm{c}$ \\
\hline & 3 & $33.2(7.3) \mathrm{ab}$ & $14.62(2.90) \mathrm{a}$ & $6.52(0.78) a$ & $65.79(8.55) b$ \\
\hline & 4 & $43.6(8.7) \mathrm{a}$ & $14.81(3.06) \mathrm{a}$ & $6.16(0.70) \mathrm{a}$ & $90.28(9.93) \mathrm{a}$ \\
\hline & 5 & $0.7(0.2) \mathrm{d}$ & $0.14(0.02) \mathrm{d}$ & $0.05(0.01) \mathrm{d}$ & $1.11(0.12) \mathrm{e}$ \\
\hline & Total & $100.4(22.0) \mathrm{A}$ & $40.60(8.12) \mathrm{A}$ & $17.74(1.80) \mathrm{A}$ & 204.49 (21.47) A \\
\hline \multirow[t]{6}{*}{ Tsoongiodendron odorum } & 1 & $9.9(3.2) b$ & $5.65(1.05) b$ & $2.77(0.33) b$ & $19.78(2.07) \mathrm{c}$ \\
\hline & 2 & $29.7(7.1) \mathrm{a}$ & 14.57 (2.69) a & $6.75(0.76) \mathrm{a}$ & $68.48(8.42) \mathrm{a}$ \\
\hline & 3 & $13.6(3.1) b$ & $5.04(0.94) b$ & $2.19(0.26) b$ & $27.22(2.85) b$ \\
\hline & 4 & $8.8(1.6) b$ & $2.90(0.55) \mathrm{c}$ & $1.20(0.15) \mathrm{c}$ & $18.27(2.00) \mathrm{c}$ \\
\hline & 5 & $1.0(0.3) \mathrm{c}$ & $0.13(0.02) \mathrm{d}$ & $0.04(0.01) \mathrm{d}$ & $1.13(0.12) \mathrm{d}$ \\
\hline & Total & $63.1(14.8) \mathrm{AB}$ & $28.29(5.92) \mathrm{AB}$ & 12.95 (1.35) B & 134.88 (15.91) B \\
\hline \multirow[t]{6}{*}{ Castanopsis carlesii } & 1 & $12.9(3.8) \mathrm{a}$ & $7.47(1.33) \mathrm{a}$ & $3.47(0.58) \mathrm{a}$ & $30.63(3.85) \mathrm{a}$ \\
\hline & 2 & $13.1(2.8) \mathrm{a}$ & $6.80(1.28) \mathrm{a}$ & $3.09(0.55) \mathrm{a}$ & $38.76(4.84) \mathrm{a}$ \\
\hline & 3 & $12.6(2.7) \mathrm{a}$ & $4.16(0.83) \mathrm{b}$ & $1.81(0.33) \mathrm{b}$ & $27.04(3.73) b$ \\
\hline & 4 & $8.6(1.8) \mathrm{a}$ & $1.90(0.34) \mathrm{c}$ & $0.74(0.09) \mathrm{c}$ & $13.11(1.53) \mathrm{c}$ \\
\hline & 5 & $0.8(0.2) \mathrm{b}$ & $0.13(0.02) \mathrm{d}$ & $0.04(0.01) \mathrm{d}$ & $0.94(0.12) \mathrm{d}$ \\
\hline & Total & 48.0 (11.6) B & $20.46(3.80) \mathrm{BC}$ & $9.15(1.02) \mathrm{C}$ & $110.48(11.82) \mathrm{B}$ \\
\hline \multirow[t]{6}{*}{ Cinnamomum chekiangense } & 1 & $16.1(4.8) \mathrm{a}$ & $7.90(1.55) \mathrm{a}$ & $3.70(0.71) \mathrm{a}$ & $33.18(4.14) \mathrm{a}$ \\
\hline & 2 & $4.6(1.0) \mathrm{b}$ & $1.88(0.33) \mathrm{c}$ & $0.87(0.15) \mathrm{d}$ & $8.65(0.95) \mathrm{c}$ \\
\hline & 3 & $11.7(2.6) \mathrm{a}$ & $4.10(0.77) b$ & $1.78(0.22) \mathrm{b}$ & $20.09(2.16) \mathrm{b}$ \\
\hline & 4 & $11.1(2.4) \mathrm{a}$ & $2.99(0.53) b$ & $1.19(0.16) \mathrm{c}$ & $18.84(2.44) b$ \\
\hline & 5 & $5.4(1.5) \mathrm{b}$ & $0.65(0.11) \mathrm{d}$ & $0.19(0.03) \mathrm{e}$ & $4.29(0.46) \mathrm{d}$ \\
\hline & Total & $48.9(11.5) \mathrm{B}$ & $17.52(2.78) \mathrm{C}$ & $7.73(0.81) \mathrm{C}$ & 85.05 (8.84) C \\
\hline \multirow[t]{6}{*}{ Castanopsis fabri } & 1 & & - & - & - \\
\hline & 2 & $7.4(1.7) b$ & $3.26(0.64) b$ & $1.52(0.20) b$ & $15.65(1.92) b$ \\
\hline & 3 & $36.6(8.4) \mathrm{a}$ & $12.08(2.16) \mathrm{a}$ & $5.52(0.66) \mathrm{a}$ & $62.82(8.04) \mathrm{a}$ \\
\hline & 4 & $4.5(1.0) \mathrm{b}$ & $1.21(0.22) \mathrm{c}$ & $0.50(0.05) \mathrm{c}$ & $6.47(0.74) \mathrm{c}$ \\
\hline & 5 & $1.3(0.4) \mathrm{c}$ & $0.20(0.03) \mathrm{d}$ & $0.08(0.01) \mathrm{d}$ & $1.28(0.17) \mathrm{d}$ \\
\hline & Total & $49.8(10.4) \mathrm{B}$ & 16.75 (2.64) C & $7.62(0.85) \mathrm{C}$ & $86.22(9.48) \mathrm{C}$ \\
\hline
\end{tabular}

and therefore have been protected from cutting (Qiu 2010). Furthermore, the patterns of CWD mass within size classes at a site can usually be linked to forest history and disturbance (Currie and Nadelhoffer 2002). Our A. gracilipes forest ( $\sim 150$ years old $)$ had undergone some single-tree mortality and small-scale wind disturbances. As a result, significant quantities of mass were present in CWD across a greater range of size categories (Table 3). Above $50 \%$ of the CWD mass in five natural forests was dominated by moderate and high decayed components (Fig. 1), which might reflect a comparatively higher decomposition rates of woody debris in our study sites. Appropriate climate conditions in the study area provides advantageous conditions for microorganisms to thrive, and this may contribute to CWD decay (Cui and Dai 2008). On the other hand, differences in CWD decay stages are probably due to species differences and disturbance (Eaton and Lawrence 2006). Mattson et al. (1987) found a 10-fold variation in decay rates among species in a mixed hardwood forest in North Carolina. In our study area, CWD in the C. chekiangense forest was composed mainly of logs of C. chekiangense, which is caused by recent high windthrow mortality. Therefore most CWD was in decay class 1 . It is necessary to develop site- and species-specific decay classification schemes for natural forests in Wanmulin Nature Reserve.

We found that there was a decrease in density as decay progressed from decay class 1 (or 2) to 5 in the A. gracilipes (62\%), T. odorum (77\%), C. carlesii (72\%), C. chekiangense (76\%) and C. fabri (66\%) forests. This result was consistent with the various sources that have reported a gradual decrease in density of coniferous and deciduous tree components with decay class increase (Creed et al. 2004; Tobin et al. 2007; 
Beets et al. 2008; Yang et al. 2010). The linking of density to decay class is useful when undertaking an inventory of $\mathrm{C}$ stocks of CWD (Olajuyigbe et al. 2011).

The result of the decrease in $\mathrm{C}: \mathrm{N}$ ratio with decay progressing in this study indicates that the $\mathrm{C}: \mathrm{N}$ ratio could be used as a potential indicator of decay stages. This phenomenon was also observed in some earlier studies (Creed et al. 2004; Palviainen et al. 2010; Yang et al. 2010). The decrease in $\mathrm{C}$ concentration and increase in $\mathrm{N}$ concentration resulted in a declining $\mathrm{C}: \mathrm{N}$ ratio with the decay process. In the case of angiosperm wood, there is a decrease in $\mathrm{C}$ concentration as it becomes more decayed (Harmon et al. 2013). The decline in $\mathrm{C}$ concentration is striking, as low as $29 \%$ in class 5 in the $C$. chekiangense forest (Table 4). The likely explanation is the prevalence of white-rot. White-rots, which degrade lignin, are more common in angiosperms. This might lead to a decrease in $\mathrm{C}$ concentration as decomposition proceeds (Gilbertson 1980). We have observations of light color in many of the highly decayed CWD, which might be associated with white-rots. The other reason for $\mathrm{C}$ concentration decline would be a large increase in ash due to mixing with soil (Harmon et al. 2013), while the $\mathrm{N}$ concentration increased as the mass of CWD declined-possibly due to fungal and bacterial $\mathrm{N}$ fixation (Yang et al. 2010). The strong correlation between the change in $\mathrm{C}: \mathrm{N}$ ratio and the density reduction with decay progression revealed an important interaction between the chemical and physical properties of CWD. The density of CWD integrates both external and internal properties of CWD and is a valuable diagnostic tool for assessing its $\mathrm{C}: \mathrm{N}$ ratio (Creed et al. 2004; Yang et al. 2010).

\section{2 $\mathrm{C}$ and $\mathrm{N}$ pools of CWD}

As a part of the organic matter pool on the forest floor, CWD stores significant amounts of C $\left(7.62-17.74 \mathrm{Mg} \mathrm{ha}^{-1}\right)$ in oldgrowth natural forests of the Wanmulin Nature Reserve. However, the C pool of CWD in our study was much lower than that of old-growth and primary coastal rainforests in southern Chile (Carmona et al. 2002) and at the lower end of the range reported for tropical forests $(<1$ to $>30 \mathrm{Mg} \mathrm{C}$ $\mathrm{ha}^{-1}$ ) (Clark et al. 2002; Rice et al. 2004; Baker et al. 2007; Yang et al. 2010). As such, the percent of total aboveground $C$ in CWD provides a better indication of the importance of CWD to ecosystem C storage, and a better means of comparing CWD C across forests (Iwashita et al. 2013). Total CWD $\mathrm{C}$ storage in this study accounted for an estimated mean value of $5 \%$ of total aboveground $\mathrm{C}$ storage, ranging from $4 \%$ to $9 \%$ across five forests (unpublished data). This value was lower than estimates of 19-33\% for tropical forests (Delaney et al. 1998; Clark et al. 2002; Rice et al. 2004; Baker et al.
2007; Palace et al. 2008). Thus, the low quantity of CWD C stored in these forests appears to be driven primarily by the relatively low amount of aboveground live biomass contained in these forests compared to other tropical wet forests. Also, carbon in CWD in the five natural forests amounted to about $10 \%$ of the total soil $\mathrm{C}$ store to $1 \mathrm{~m}$ depth (unpublished data), which was slightly lower than that of unmanaged beechdominated mixed deciduous stands $(15 \%)$ in Denmark (Vesterdal and Christensen 2007). N stock in CWD in these forests was similar to those reported in other studies (Idol et al. 2001; Currie and Nadelhoffer 2002), while it was higher than in a natural mixed deciduous forest in Korea (Kim et al. 2006). It was estimated that CWD could account for about $6-15 \%$ of the total aboveground $\mathrm{N}$ pool across studied forests (unpublished data), similar to the results of Laiho and Prescott (1999). Several factors such as climate, substrate quality and forest disturbance have been suggested to account for the variation in inputs and outputs of woody debris and consequently the $\mathrm{C}$ and $\mathrm{N}$ stocks of CWD in different forests (Harmon et al. 1986; Clark et al. 2002; Yang et al. 2010). Given the important value of CWD for $\mathrm{C}$ and $\mathrm{N}$ cycling, more research into CWD dynamics across this region is critically required.

\subsection{Conservation implications}

Natural evergreen broad-leaved forests are valuable forest types within China. Recently, however, there has been an apparent tendency towards replacing these oldgrowth evergreen broad-leaved forests with plantations of coniferous species such as Pinus massoniana Lamb. and Chinese fir (Cunninghamia lanceolata [Lamb.] Hook). As a consequence, plantation forests lack some key old-growth characteristics (Yan et al. 2007). The abundance of CWD, especially large logs, is thought to be the most outstanding structural characteristics of old-growth primary forest (Harmon et al. 1986; Siitonen et al. 2000). In any case, the time required to develop CWD patterns and characteristics (especially largerdiameter log distribution) is still long (Yang et al. 2008; Motta et al. 2010). Recovering time for CWD structure and composition similar to primary forest may exceed several centuries. On the other hand, the interaction between CWD, $\mathrm{C}$ and nutrient storage can be used in forest ecosystem health management (Guo et al. 2006). Therefore, it is very important to preserve the current natural forest and maintain the structural and functional integrity of CWD.

Acknowledgments We are grateful to Prof. Yiqing Li, the associate editor (Andreas Bolte) and two anonymous reviewers for their helpful comments and suggestions. This work was financed by the National Natural Science Foundation of China (No. 31370615 and 31130013). 


\section{References}

Baker TR, Coronado ENH, Phillips OL, Martin J, van der Heijden GMF, Garcia M, Espejo JS (2007) Low stocks of coarse woody debris in a southwest Amazonian forest. Oecologia 152:495-504

Beets PN, Hood IA, Kimberley MO, Oliver GR, Pearce SH, Gardner JF (2008) Coarse woody debris decay rates for seven indigenous tree species in the central North Island of New Zealand. For Ecol Manag 256:548-557

Carmona MR, Armesto JJ, Aravena JC, Perez CA (2002) Coarse woody debris biomass in successional and primary temperate forests in Chiloé Island, Chile. For Ecol Manag 164:265-275

Castagneri D, Garbarino M, Berretti R, Motta R (2010) Site and stand effects on coarse woody debris in montane mixed forests of Eastern Italian Alps. For Ecol Manag 260:1592-1598

Chave J, Muller-Landau HC, Baker TR, Easdale TA, Ter Steege H, Webb CO (2006) Regional and phylogenetic variation of wood density across 2456 neotropical tree species. Ecol Appl 16:2356-2367

Chen H, Xu ZB (1991) History, current situation and tendency of CWD ecological research (in Chinese with English abstract). Chin J Ecol $10: 45-50$

Clark DB, Clark DA, Brown S, Oberbauer SF, Veldkamp E (2002) Stocks and flows of coarse woody debris across a tropical rain forest nutrient and topography gradient. For Ecol Manag 164:237-248

Creed IF, Webster KL, Morrison DL (2004) A comparison of techniques for measuring density and concentrations of carbon and nitrogen in coarse woody debris at different stages of decay. Can J For Res 34: 744-753

Cui BK, Dai YC (2008) Wood-rotting fungi in eastern China 2. A new species of Fomitiporia (Basidiomycota) from Wanmulin Nature Reserve, Fujian Province. Mycotaxon 105:343-348

Currie WS, Nadelhoffer KJ (2002) The imprint of land-use history: patterns of carbon and nitrogen in downed woody debris at the Harvard forest. Ecosystems 5:446-460

Dai LM, Xu ZB, Chen H (2000) Storage dynamics of fallen trees in the broad-leaved and Korean pine mixed forest (in Chinese with English abstract). Acta Ecol Sin 20:412-416

Delaney M, Brown S, Lugo AE, Torres-Lezama A, Bello-Qunitero N (1998) The quantity and turnover of dead wood in permanent forest plots in six life zones of Venezuela. Biotropica 30:2-11

Deng HB, Xiao BY, Dai LM, Wang QL, Wang SX (2002) Advance in ecological studies on in-stream coarse woody debris (in Chinese with English abstract). Acta Ecol Sin 22:87-93

Eaton JM, Lawrence D (2006) Woody debris stocks and fluxes during succession in a dry tropical forest. For Ecol Manag 232:46-55

Forrester JA, Mladenoff DJ, Gower ST, Stoffel JL (2012) Interactions of temperature and moisture with respiration from coarse woody debris in experimental forest canopy gaps. For Ecol Manag 265:124-132

Gilbertson RL (1980) Wood-rotting fungi of North America. Mycologia 72:1-49

Goodburn JM, Lorimer CG (1998) Cavity trees and coarse woody debris in old-growth and managed northern hardwood forests in Wisconsin and Michigan. Can J For Res 28:427-438

Grove SJ, Meggs J (2003) Coarse woody debris, biodiversity and management: a review with particular reference to Tasmanian wet eucalypt forests. Aust For 66:258-272

Guo LB, Bek E, Gifford RM (2006) Woody debris in a 16-year old Pinus radiata plantation in Australia: mass, carbon and nitrogen stocks, and turnover. For Ecol Manag 228:145-151

Harmon ME, Sexton J (1996) Guidelines for measurements of woody detritus in forest ecosystems. US LTER publication no. 20, US LTER network office, University of Washington, Seattle, WA, pp 1-34

Harmon ME, Franklin JF, Swanson FJ, Sollins P, Gregory V, Lattin JD, Anderson NH, Cline SP, Aumen NG, Lienkaemper GW, Cromack
KJ, Cummins KW (1986) Ecology of coarse woody debris in temperate ecosystems. Adv Ecol Res 15:133-302

Harmon ME, Whigham DF, Sexton J, Olmsted L (1995) Decomposition and mass of woody detritus in the dry tropical forests of the northeastern Yucatan peninsula, Mexico. Biotropica 27:305-316

Harmon ME, Fasth B, Woodall CW, Sexton J (2013) Carbon concentration of standing and downed woody detritus: effects of tree taxa, decay class, position, and tissue type. For Ecol Manag 291:259-267

Hou P, Pan CD (2001) Coarse woody debris and its function in forest ecosystem (in Chinese with English abstract). Chin J Appl Ecol 12: 309-314

Idol TW, Pope PE, Figler RA, Ponder F Jr (2001) Characterization of coarse woody debris across a 100 year chronoseqeuence of upland oak-hickory forests. For Ecol Manag 149:153-161

Iwashita DK, Litton CM, Giardina CP (2013) Coarse woody debris carbon storage across a mean annual temperature gradient in tropical montane wet forest. For Ecol Manag 291:336-343

Keenan RJ, Prescott CE, Kimmins JP (1993) Mass and nutrient content of woody debris and forest floor in western red cedar and western hemlock forests on northern Vancouver Island. Can J For Res 23: 1052-1059

Kent M, Coker P (1992) Vegetation description and analysis, a practical approach. Wiley, NY, pp 167-169

Kim RH, Son Y, Lim JH, Lee IK, Seo KW, Koo JW, Noh NJ, Ryu SR, Hong SK, Ihm BS (2006) Coarse woody debris mass and nutrients in forest ecosystems of Korea. Ecol Res 21:819-827

Laiho R, Prescott CE (1999) The contribution of coarse woody debris to carbon, nitrogen, and phosphorus cycles in three Rocky Mountain coniferous forests. Can J For Res 29:1592-1603

Li LH, Xing XR, Huang DM, Liu CD, He JY (1996) Storage and dynamics of coarse woody debris in Castanopsis eyrei forest of Wuyi mountain, with some considerations for its ecological effects (in Chinese with English abstract). Acta Phytoecol Sin 20:132-143

Li LH, Dang GD, Wang TJ, Zhao LG (1998) Coarse woody debris in an Abies fargesii forest in the Qinling mountains (in Chinese with English abstract). Acta Phytoecol Sin 22:434-440

Lin CF, Yang YS, Guo JF, Chen GS, Xie JS (2011) Fine root decomposition of evergreen broadleaved and coniferous tree species in midsubtropical China: dynamics of dry mass, nutrient and organic fractions. Plant Soil 338:311-327

Liu WY, Fox JED, Xu ZF (2002) Biomass and nutrient accumulation in montane evergreen broad-leaved forest (Lithocarpus xylocarpus type) in Ailao Mountains, SW China. For Ecol Manag 158:223-235

Mackensen J, Bauhus J, Webber E (2003) Decomposition rates of coarse woody debris - a review with particular emphasis on Australian tree species. Aust J Bot 51:27-37

Mattson KG, Swank WT, Waide JB (1987) Decomposition of woody debris in a regenerating, clear-cut forest in the southern Appalachians. Can J For Res 17:712-721

Motta R, Berretti R, Castagneri D, Lingua E, Nola P, Vacchiano G (2010) Stand and coarse woody debris dynamics in subalpine Norway spruce forests withdrawn from regular management. Ann For Sci 67:803

Muller RN (2003) Landscape patterns of change in coarse woody debris accumulation in an old-growth deciduous forest on the Cumberland Plateau, southeastern Kentucky. Can J For Res 33:763-769

Olajuyigbe SO, Tobin B, Gardiner P, Nieuwenhuis M (2011) Stocks and decay dynamics of above- and belowground coarse woody debris in managed Sitka spruce forests in Ireland. For Ecol Manag 262:1109 1118

Palace M, Keller M, Silva H (2008) Necromass production: studies in undisturbed and logged Amazon forests. Ecol Appl 18:873-884

Palviainen M, Finér L, Laiho R, Shorohova E, Kapitsa E, VanhaMajamaa I (2010) Carbon and nitrogen release from decomposing Scots pine, Norway spruce and silver birch stumps. For Ecol Manag 259:390-398 
Qiu XW (2010) Protection history of Wanmulin and its implication on ecological construction (in Chinese with English abstract). J Beijing For Univ (Soc Sci Edit) 9:6-9

Rice AH, Pyle EH, Saleska SR, Hutyra L, Palace M, Keller M, de Camargo PB, Portilho K, Marques DF, Wofsy SC (2004) Carbon balance and vegetation dynamics in an old-growth Amazonian forest. Ecol Appl 14:S55-S71

Santiago LS (2000) Use of coarse woody debris by the plant community of a Hawaiian montane cloud Forest. Biotropica 32:633-641

Schlegel BC, Donoso PJ (2008) Effects of forest type and stand structure on coarse woody debris in old-growth rainforests in the Valdivian Andes, south-central Chile. For Ecol Manag 255:1906-1914

Siitonen J, Martikainen P, Punttila P, Rauh J (2000) Coarse woody debris and stand characteristics in mature managed and old-growth boreal mesic forests in southern Finland. For Ecol Manag 128:211-225

Sollins P, Cline SP, Verhoeven T, Sachs D, Spycher G (1987) Patterns of $\log$ decay in old-growth Douglas-fir forests. Can J For Res 17:15851595

Spies TA, Franklin JF, Thomas TB (1988) Coarse woody debris in Douglas-fir forest of western Oregon and Washington. Ecology 69:1689-1702

Tang XL, Zhou GY (2005) Coarse woody debris biomass and its potential contribution to the carbon cycle in successional subtropical forests of Southern China (in Chinese with English abstract). Acta Phytoecol Sin 29:559-568

Tang XL, Zhou GY, Zhou X, Wen DZ, Zhang QM, Yin GC (2003) Coarse woody debris in monsoon evergreen broad-leaved forests of Dinghushan nature reserve (in Chinese with English abstract). Acta Phytoecol Sin 27:484-489
Tobin B, Black K, McGurdy L, Nieuwenhuis M (2007) Estimates of decay rates of components of coarse woody debris in thinned Sitka spruce forests. Forestry 80:455-469

Vesterdal L, Christensen M (2007) The carbon pools in a Danish seminatural forest. In: Hahn K, Emborg J (eds) Suserup Skov: structure and processes in a temperate, deciduous forest reserve. Ecological Bulletins, vol 52. Wiley-Blackwell, Oxford, pp 113-121

Webster CR, Jenkins MA (2005) Coarse woody debris dynamics in the southern Appalachians as affected by topographic position and anthropogenic disturbance history. For Ecol Manag 217:319-330

Wu ZY (1980) The vegetation of China (in Chinese). Science, Beijing

Yan ER, Wang XH, Huang JJ, Zeng FR, Gong L (2007) Long-lasting legacy of forest succession and forest management: characteristics of coarse woody debris in an evergreen broad-leaved forest of Eastern China. For Ecol Manag 252:98-107

Yang LY, Dai LM, Zhang YJ (2002) Storage and decomposition of fallen wood in dark coniferous forest on the North slope of Changbai mountain (in Chinese with English abstract). Chin J Appl Ecol 13: 1069-1071

Yang YS, Guo JF, Chen GS, Xie JS, Gao R, Li Z, Jin Z (2005) Litter production, seasonal pattern and nutrient return in seven natural forests compared with a plantation in southern China. Forestry 78: $403-415$

Yang LP, Liu WY, Ma WZ (2008) Woody debris stocks in different secondary and primary forests in the subtropical Ailao Mountains, southwest China. Ecol Res 23:805-812

Yang FF, Li YL, Zhou GY, Wenigmann KO, Zhang DQ, Wenigmann M, Liu SZ, Zhang QM (2010) Dynamics of coarse woody debris and decomposition rates in an old-growth forest in lower tropical China. For Ecol Manag 259:1666-1672 